\title{
PUBLIC SECTOR PROJECT MANAGEMENT EFFICIENCY PROBLEMS, CASE OF LATVIA
}

\author{
Emīls PŪlmanis ${ }^{1}$
}

State Regional Development Agency (Latvia)

\begin{abstract}
The application of Project Management (PM) tools and techniques in public sector is gradually becoming an important issue in developing economies, especially in a new development country like Latvia where projects of different size and structures are undertaken. The paper examined the application of the project management practice in public sector in Latvia. Public sector project management in Latvia become popular in recent years as there is different type of public funding sources available. The paper describes the public sector project management practice in Latvia. Study shows that public sector project maturity level is low and should be improved. Research period covers the time period from January 2013 - March 2013.

KEYWORDS: project management, project planning and initialization, efficiency.
\end{abstract}

JEL CODES: O220, H430, H540

\section{Introduction}

Government and organizations usually embark on different projects with the aim of creating new service or improving the functional efficiency of the existing ones. All these projects require appropriate skills and techniques that go beyond technical expertise only, but encompass good and sound skills to manage limited budgets, and monitor shrinking schedules and unpredicted outcomes, while at the same time dealing with people and organizational issues (Abbasi and Al-Mharmah, 2000). The application of project management practice in public sector has been identified as an efficient approach which would help in upgrading management capabilities and enable public sector to efficiently complete projects and attain developmental objectives (Arnaboldi, Azzone and Savoldelli, 2004).

Recipients of funding - both public authorities, public institutions and businesses, is a major challenge for financial gain and to promote public welfare. However, the benefits bring with them the responsibility for waste and financial records and reports on practical goals. Funding Administration requires thorough knowledge and understanding of the law. A growing number of mass media and the administration of financial instruments institutional statements we hear that a large number of project applications, which is a low quality place. Now that the errors and weaknesses in project development and administration are unacceptable, more and more to think of an effective system that would be according to the conventional project management theory. Such a system would be built at local level, ensuring appropriate project specialist, but the program level, i.e. need to improve the administration of financial instruments including methodical and regulatory documents update and synchronize project management theory to improve the project initiation process and ensure the quality of project applications development, thus resulting in an effective and rational use of taxpayers' money (Pulmanis, 2012).

\footnotetext{
Emīls Pūlmanis - State Regional Development Agency, Senior expert, Phd. cand., MSc.proj.mgmt E-mail: Emils.Pulmanis@gmail.com

Tel.: +37126896748
} 
Viewed in a broader sense, it can be concluded that the planning process phenomenon consists of three connected plans: the strategic plan, functional plans and project plans. Project plans are a reflection of the strategic plan, while functional plans represent a detailed guide to using resources to achieve a set purpose. Project realization planning represents a rational determination of how to initiate, sustain and complete a project (Cleland, 1999).

The object of the research is public sector project management.

The aim of the article is to evaluate project planning and initialization practice in public sector in Latvia. The objectives of the article are as follows:

- assess the public sector project initialization practice and identify the problem areas of public sector project management in Latvia,

- analyze theoretical background of project management concepts as well as project initialization and planning process in public administration

- provide proposals for public sector project management process improvement.

The research methods used in the article include the project and program empirical data analysis and literature review as well as survey based on questionnaire.

\section{Project management concept}

The term project is described in different ways in the research literature. This is illustrated below:

- Project is defined as a temporary endeavor undertaken to create a unique product or service, temporary means that the project has a definite ending point, and unique means that the product or service differs in some distinguishing way from all similar products or services (PMI, 2013, p. 4).

- Project has been termed as a human endeavor and may legitimately be regarded by its stakeholders as a project when it encompasses a unique scope of work that is constrained by cost and time, the purpose of which is to create or modify a product or service so as to achieve beneficial change defined by quantitative and qualitative objectives (Cooke-Davies, 2001, p. 20).

- Project is described as a "value creation undertaking based on specifics, which is completed in a given or agreed timeframe and under constraints, including resources and external circumstances" (Ohara, 2005, p. 15).

- A project is a regarded as a business case that indicates the benefits and risks of the venture, demonstrating a unique set of deliverables, with a finite life-span, by using identified resources with identified responsibilities (Bradley, 2002). The common themes in these definitions is that projects are unique in their output, having a definite starting and ending point, are temporary in nature and are carried out to manifest the organization's strategic objectives. These temporary structures are playing a vital role in today's modern organizations and a growing interest is recorded in the significance of these temporary structures in organizations.

Project management is defined in different ways in the research literature. Some of these definitions are as follows:

- Project Management is describe as a collection of tools and techniques to direct the use of diverse resource toward the accomplishment of a unique, complex, one time task within time, cost and quality constraint. Each task requires a particular mix of these tools and techniques structured to fit the task environment and life cycle (from conception to completion) of the task (Oisen, 1971: Cited in Atkinson, 1999).

- Project Management is express as planning, organizing, monitoring and controlling of all the aspects of a project and the motivation of all the involved stakeholders to achieve the project objectives safely and within agreed time, cost and performance criteria (APM, 1995). 
- Project management is term as an application of knowledge, skills, tools and techniques to project activities to meet project requirements. Project Management is accomplished through the application and integration of the project management processes of initiation, planning, executing, monitoring and controlling and closing (PMI, 2013).

- Project management is also articulated as a professional's capability to deliver, with due diligence, a project product that fulfills a given mission, by organizing a dedicated project team, effectively combining the most appropriate technical and managerial methods and techniques and devising the most efficient and effective breakdown and implementation routes (Ohara, 2005).

Turner (1996) suggested that project management could be described as the art and science of converting vision into reality whereas Atkinson (1999) argues that perhaps project management is simply an evolving phenomenon, which will remain vague enough to be non-definable. This flexibility can be regarded as its strength. In its early days the project management was solely concerned with the implementation of single project in that era (Kartam et al., 2000). But, today many organizations have embraced the concept of project management. This is mainly because of its systematic approach of managing the projects (Morgan, 1987). It's a way to generate consistent results when undertaking new initiatives and a powerful business tool that can transform an organization's ability to perform well (Artto et. al., 2008).

Conceptualization according to Pinto (2007) refers to the development of the initial goal and technical specification for a project. The scope of work is determined, necessary resources (people, money, material \& machine) identified, and important organizational contributions or stakeholders signed on. Also, feasibility study is conducted at this stage to investigate whether the project can be continued or not. Planning is the stage in which detailed specifications, schematic, schedules and other plans are developed. It is also a stage where the project solution is further developed in as much detail as possible and steps necessary to meet the project's objectives are put in place. At this stage the individual pieces of the project called work packages are broken down, individual assignments made, and the process for completion clearly delineated. Project schedule, the actual work and the estimated cost of completion are also identified. Anything that might pose a threat to the successful completion of the project is also identified at this stage. Finally all the project stakeholders must be identified at this stage of the project so as to establish a communication plan that describes information needed and the delivery method to be used to keep stakeholders informed (Patel, 2008).

Project management is defined as an application of knowledge, skills, tools and techniques to project activities to meet project requirements. This is accomplished through the application and integration of the project management processes of initiation, planning, executing, monitoring and controlling and closing (PMI, 2013). Mintzberg (1983) cited in Soderlund (2004b) states that most of the emergent industries since world-war II are project intensive. This widespread use of projects in organizations demanded an approach that can efficiently manage these temporary endeavors which are critical to the organizations strategic objectives. This led the researchers and professionals of the field to devise an approach that can efficiently manage the projects. Initially the focus of research on projects was exclusively on the implementation of a single project (Crawford et al, 2006). Project research in general now spans a variety of level of analysis. Concept such as the management of projects and the management by projects clearly point to the current devotion of project research (Soderlund, 2004a \&b). An important factor here is that the researchers suggest management of projects to be at the core of understanding the modern firm (ibid). Public sector organizations are differentiated in comparison with their commercial counterparts in the private sector. There is no profit maximizing focus, little potential for income generation and, generally speaking, no bottom line against which performance can be measured (Boland and Fowler, 2000). The vast majority of public sector organizations still generate most of their income from the State (ibid). However, the capability of the public sector is pivotal to the growth of the economy (Rwelamila, 2007). Furthermore, the need for project management expertise in public sector organizations has become fundamental in order to deal with the enormous responsibility of managing a number of projects (ibid). 
In less developed countries the implementation of project management tools and techniques is still in its early phases of development. It is a relatively modern practice that attempts to achieve planned objectives within specific time and cost limits, through optimum use of resources and using an integrated planning and control system (Abbasi and Al-Mharmah, 2000). According to Schlichter (1999) project management has led a number of organizations to be more effective and efficient in delivery of their products and services, to have more accurate budgeting and scheduling and improved productivity. The growth and acceptance of project management is continuing to increase as resources become scarce in less developed countries.

\section{Theoretical aspects of project initialization and planning}

Effective and accurate planning is required at the start of the project for the project to be successful. In public sector projects the planning and decision making inevitably become political activities (Dennis, 2000). Planning becomes a process not only of analyzing problems, goals and alternative course of action, but also of advocating position, influencing behavior and intervening in the policy making process to affect the outcome of decisions (Rondinelli, 1976). Planning consists of a set of procedures whereby decision makers attempt to:

- Identify and define major problems and goals.

- Analyze relevant environment and strategic conditions.

- Project trends, needs, opportunities and constraints.

- Transform goals into operational targets.

- Identify alternatives course of action for achieving goals and targets.

- Calculate cost and benefit of each alternative.

- Estimate the probabilities of future events.

- Projected trends occurring.

- Determine the potential non-economic gains.

- Losses and consequences of each alternative.

- Choose the optimal alternatives or set of actions.

- Integrate the chosen course of action into a comprehensive plan.

In addition to understand the above characteristics of planning in a public project there are number of processes that need to be followed to plan project effectively. These are:

- Defining the deliverables.

- Defining the work packages.

- Estimating the work.

- Scheduling the work packages.

- Managing resource availability.

- Creating the budget.

- Integrating schedule and budget.

- Identifying key performance Indicators.

- Identifying critical success factors (Harpum, 2004).

Procurement / Contracting Strategy in Public Sector Projects Spittler and McCracken (1996) states that by choosing a properly matched contracting strategy the chances of projects success can increase.

Author analysis of the scientific literature in the field of project management found that very little role has paid to project initiation and the problem definition importance in the frame of project management. Study shows very broadly analyses and present methods and tools for project planning and problem solutions. British PRINCE2 project management standard requires that in some situations, a feasibility study might be required to investigate the situation and determine options for the way ahead. Using PRINCE2, the optimum approach would be to handle the study as a separate and distinct project and then operate a second project to implement the results of the study. 
The America's national project management standard PMBOK defines project scope planning as "the process of developing a written scope statement as the basis for future project decisions including, in particular, the criteria used to determine if the project or phase has been completed successfully" (PMBOK, 2008).

Problem analysis identifies the existing situation and establishes the 'cause and effect' relationships between the problems that exist. It involves three steps:

1. Precise definition of the framework and subject of analysis.

2. Identification of the major problems and dangers faced by target groups.

3. Visualization of the situation.

The recurring costs of investment projects on completion will have to be clearly understood and estimated by Public Bodies before embarking on the decision to go ahead with the projects. Investment projects may be funded from Government-owned resources, grants or loans from foreign institutions and/or by the private sector.

According to A. Walton project planning may be considered a form of information development and communications. As the project team develops the project plan, the project team should learn more about the project goals, strategies, and team member roles. The project objectives then can be decided in terms of cost, schedule, and technical performance. Satisfaction of project goals is accomplished through the completion of the project work packages. The project strategy is a plan of action with accompanying policies, procedures, and resource allocation schemes, providing general direction of how the organizational effort will be used to accomplish project goals and project objectives. Simultaneous project planning is the process of having the project team considers all aspects, issues, and resources required for the project plan on a concurrent basis. Concurrent planning means that everything that can or might impact the project is reviewed during the planning phase to ensure that an explicit decision is made concerning the role that all resources, however modest, might have on the project (Walton, 1996).

The Project should be defined in the initialization phase, and the definition should show that the project will be conducted in a logical and proper manner (Charvat, 2002).

Project problems are ordinarily complex, consisting of many aspects that require analysis and insight (Heerkens, 2007). We need to invest an appropriate amount of time to fully understand all aspects of the problem. Very often, what appears to be the problem is actually masking a bigger, more fundamental problem. Uncovering that fundamental problem is referred to as identifying the true need.

Governments in some jurisdictions provide guidance on how to appraise proposals, using cost-benefit analysis, before committing significant funds. For example, the governments of Australia, New Zealand, the United Kingdom, and the United States provide guidance on the issues and techniques that should be considered when assessing new regulatory, revenue or capital policies, programs, and projects. Such guidance advises public sector departments and authorities on how to undertake conventional analysis however; such guidance can offer advice on a broader economic cost-benefit analysis that can be more valuable to the public interest.

P. Drucker commences by stating that an effective decision making process must go through some basic steps. These steps will not "make" the decision - it will always be a judgment call - but if the steps are ignored, the decision is not likely to be effective nor right. The 6 steps he recommends are:

1. The classification of the problem.

2. The definition of the problem.

3. The specifications which the solution to the problem must satisfy (the "boundary conditions").

4. The decision as to what is "right", rather than what is acceptable, in order to meet the boundary conditions.

5. The building into the decision of the action to carry it out.

6. The feedback which tests the validity of the decision against the actual course of events (Drucker, 2007). 
Justification of a problem situation should make sure it describes a controversy, not just lists a number of various facts. A typical mistake is to indicate in the project submission the desired situation, not describing the existing. In such a case the problem justifying the need for the project is not demonstrated. Therefore, the problem results from the problem situation. Whereas a problem situation is one that encourages formulating and solving the problem. If a problem situation is not analyzed in sufficient detail, the solution, too, can be incomplete. To justify the necessity for the project, it is best to start by describing the issue in question or the problem topicality. Municipalities are forced in their work to solve problem situations involving various target groups.

Definitely the most important thing in the project development process is the topicality of the problem and its accurate definition. The project goal is determined when performing the justified problem analysis. Next, the definition of project problems, target groups, and goals is analyzed in the project submissions of particular municipalities.

Analysis of the initiation documentation of the selected projects reveals the main mistakes in the problem situation description:

1. Project topicality is not described - no justification of the significance, importance of the problem for the specific city, in the particular period of time.

2. Some fragments mention the region or state in general, others the municipality.

3. Terms are not understood.

4. Generally known statements are used, not sustained by facts.

5. Part of that problem has been the lack of a structured approach for decision-making, project approval, and project execution.

All this can be satisfied with a sound project management methodology (Pūlmanis, 2013).

Problem solving models attempt to capture important aspects of the problem solving process. As decision-making and problem solving are intimately related, it is not surprising then that the Simon model of the decision-making process is the foundation for a number of problem solving models (Brightman, 1978; Van Gundy, 1988; Sprague, 1982).

The analysis of efficiency and effectiveness is about the relationships between inputs, outputs and outcomes. In 1957, Farrell already investigated the question how to measure efficiency and highlighted its relevance for economic policy makers. "It is important to know how far a given industry can be expected to increase its output by simply increasing its efficiency, without absorbing further resources" (Farrell, 1957). Since that time techniques to measure efficiency have improved and investigations of efficiency have become more frequent, particularly in industry. Nevertheless, the measurement of efficiency and effectiveness of public spending remains a conceptual challenge. Problems arise because public spending has multiple objectives and because public sector outputs are often not sold on the market which implies that price data is not available and that the output cannot be quantified.

Assessing the efficiency and effectiveness of public spending requires the measurement of the inputs entering into the production of public sector activities. This can be done in monetary and non-monetary (physical) terms. Compared to the private sector, the estimation of the actual costs of public sector activities is relatively complicated. While in the private sector, data are available at a very detailed level of activity, public sector accounts are typically designed differently, making it difficult to obtain information on all input costs, in particular at a disaggregated level. Estache et al. (2007) stress that public budgets are not really designed to track down specific sectorial expenditures.

Recent literature highlights especially the indirect costs, such as opportunity costs of using governmentowned assets, like school buildings and hospitals, and the allocation of government fixed costs. The higher tax burdens associated with an increase in public expenditures cannot be neglected either. This, however, would lead to an even broader approach to evaluating the impact of public policies. This paper chooses 
a more narrow approach and considers the public spending allocated to the production of a given public service, like public spending on health, education or infrastructure as a measure of input. It also takes into account the complementarities of public and private spending. An alternative approach to defining appropriate input indicators is to use non-monetary factors, like the number of civil servants deployed for a public activity or working hours spent on this activity. For instance, in the area of education the teachers/students ratio, class size and instruction time are quite common measures of inputs.

Research

Authors has elaborated survey questionnaire for local municipality project management specialists.

Questionnaire has been sent to all Latvian municipalities (in total 119), in the frame of study 97 responses has been collected (research sample is 97 out of 119, $n=97$ ). Research period is January 2013 - March 2013.

In order to obtain a mathematic all area son able view of the project planning capacity in the public sector -quantitative analysis of the survey data obtained through analysis of education, training and practical work experience aspect of the relationship with the real action methods. Quantitative analysis carried out in two steps: describing the central tendency and variation of parameters and in accordance with the empirical distribution with the normal distribution choice of parametric or non-parametric method for Inferential Statistics.

The author evaluated the public sector practice in project development and initialization processes in Latvia. In the frame of research evaluation of project problem and goal definition has been done.

Study shows that in public sector project management there is lack of deep problem and situation analysis. $45.78 \%$ of respondents elaborated project proposals based on local municipal development programs and policy planning documents and don't provide deep analysis of problems. $26.05 \%$ of respondents accepted that they don't use situation analysis methods but project proposals are elaborated based on desired situation. Still $28.17 \%$ of respondents showed that they used project management methods such as current situation analysis and research, case study methods by clarifying the factual situation and the desired situation (Figure 1).

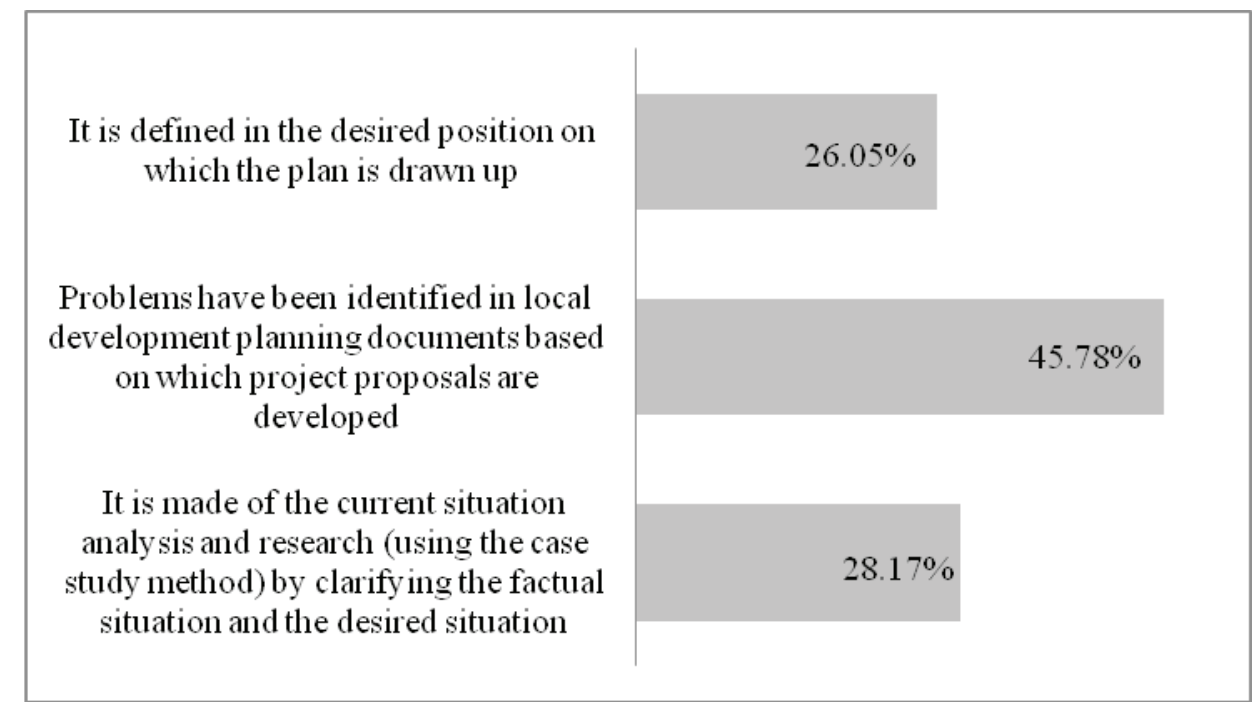

Figure 1. Problem definition practice in public sector in Latvia $(n=97)$

Source: author empirical research 


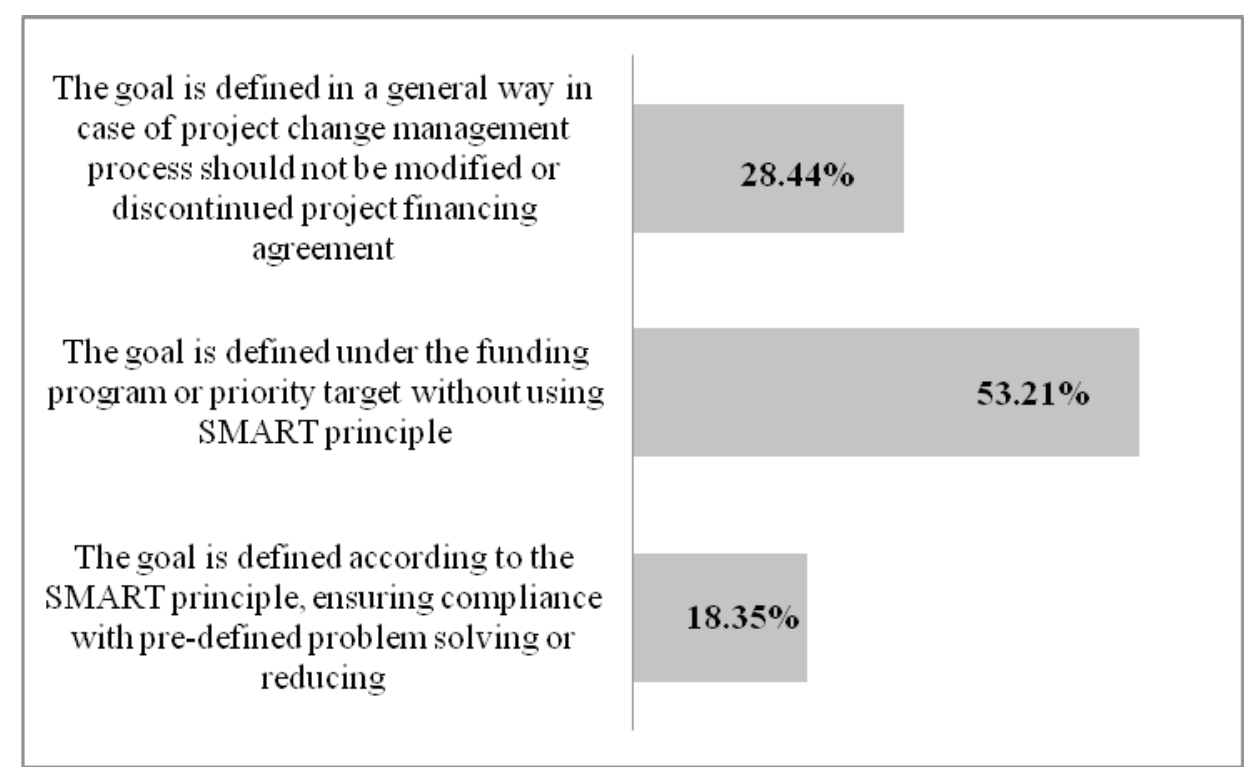

Figure 2. Project goal definition in public sector $(n=97)$

Source: author's empirical research

Goals and objectives are statements that describe what the project will accomplish, or the business value the project will achieve. The study shows that public sectors not using appropriate goal definition methods and don't use a SMART principles in definition of project goals (only $18.35 \%$ of respondents use SMART method to define their project goal). $53.21 \%$ of respondents define their project goals under the funding program or priority target without using SMART principle. Also the $28.44 \%$ of respondents define their project goals in a general way to avoid of further changes in project submission or project financing agreement (Figure 2).

Many traditional definitions of projects assume that the objectives of a project, and the methods of achieving them, are well understood throughout the project. For instance, in its body of knowledge, the UK Association of Project Managers defines a project as 'an undertaking to achieve a defined objective (Morris, 1992), and goes on to state that "generally all projects evolve through a similar "lifecycle" sequence during which there should be recognized start and finish points'.

Other definitions similarly imply clearly defined objectives and methods: an activity defined by a clear aim, appropriate objectives and supporting activities, undertaken to define start and completion criteria (Gower, 1992), and a human activity that achieves a clear objective against a time-scale (Reiss, 1992).

The author research has identified the problem aspects of project initialization and planning process in public sector in Latvia (Figure 5). As the minor problems respondents identified: frequent change of management official's decisions and initiatives, corruption, changes in responsible officials and political leaders. As the important or very important problem factors which could affect the ability and capacity of local government projects respondents defined: management official's lack of understanding of project management issues, inadequate staff motivation system, lack of human resources and lack of project management competencies and professional skills.

To evaluate public sector project management capacity and maturity author asks for respondents to undertake self-assessment and evaluate their organization capacity in project management. The study shows that public sector organization maturity is on middle/low level (Figure 6).

Project Management Maturity refers to processes, documentation, management and metrics. There are five levels of project maturity management as follows: 
Table 1. Project management maturity levels

\begin{tabular}{|l|l|}
\hline Maturity Level 5 (Highest) & $\begin{array}{l}\text { Optimized processes (All project management processes are in place, measured and } \\
\text { continually improved upon) }\end{array}$ \\
\hline Maturity Level 4 & $\begin{array}{l}\text { Managed processes (All project management processes are in place and these are } \\
\text { regularly measured) }\end{array}$ \\
\hline Maturity Level 3 & $\begin{array}{l}\text { Organizational standards and institutionalized processes (majority of project } \\
\text { management processes are in place and are used by the majority of people) }\end{array}$ \\
\hline Maturity Level 2 & $\begin{array}{l}\text { Structured processes and standards (basic processes are in place and used most } \\
\text { of the time) }\end{array}$ \\
\hline Maturity Level 1 (Lowest) & Initial process (no or little formal and/or documented processes being used) \\
\hline
\end{tabular}

Source: author's questionnaire maturity description

Research concludes that public sector bodies assessed their maturity as maturity level 3 - Organizational standards and institutionalized processes (majority of project management processes are in place and are used by the majority of people), quite big part of public sector organizations has identified their organizations in the second level of maturity - Structured processes and standards (basic processes are in place and used most of the time).

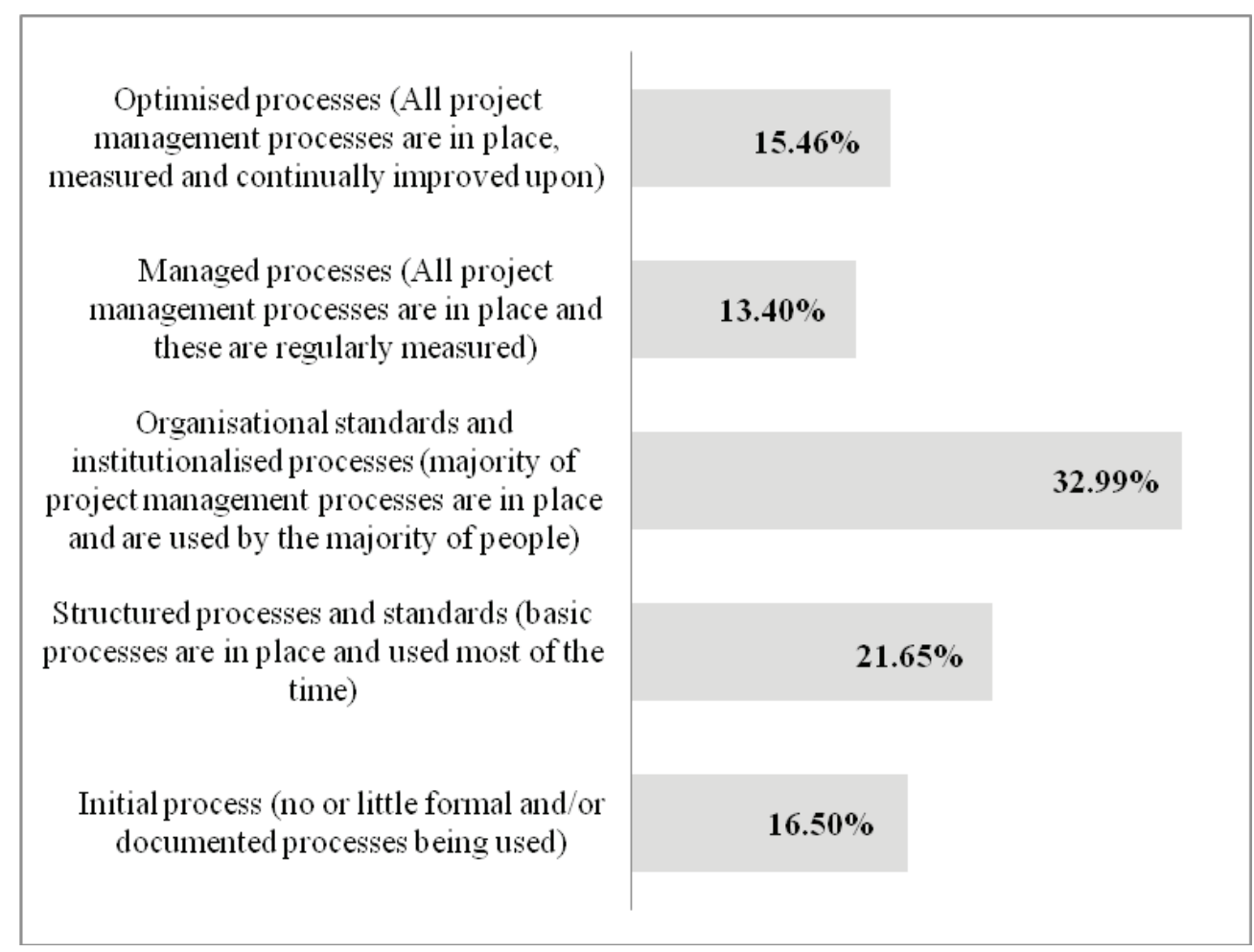

Figure 3. Public sector project management maturity self-assessment $(n=97)$

Source: author's empirical research 


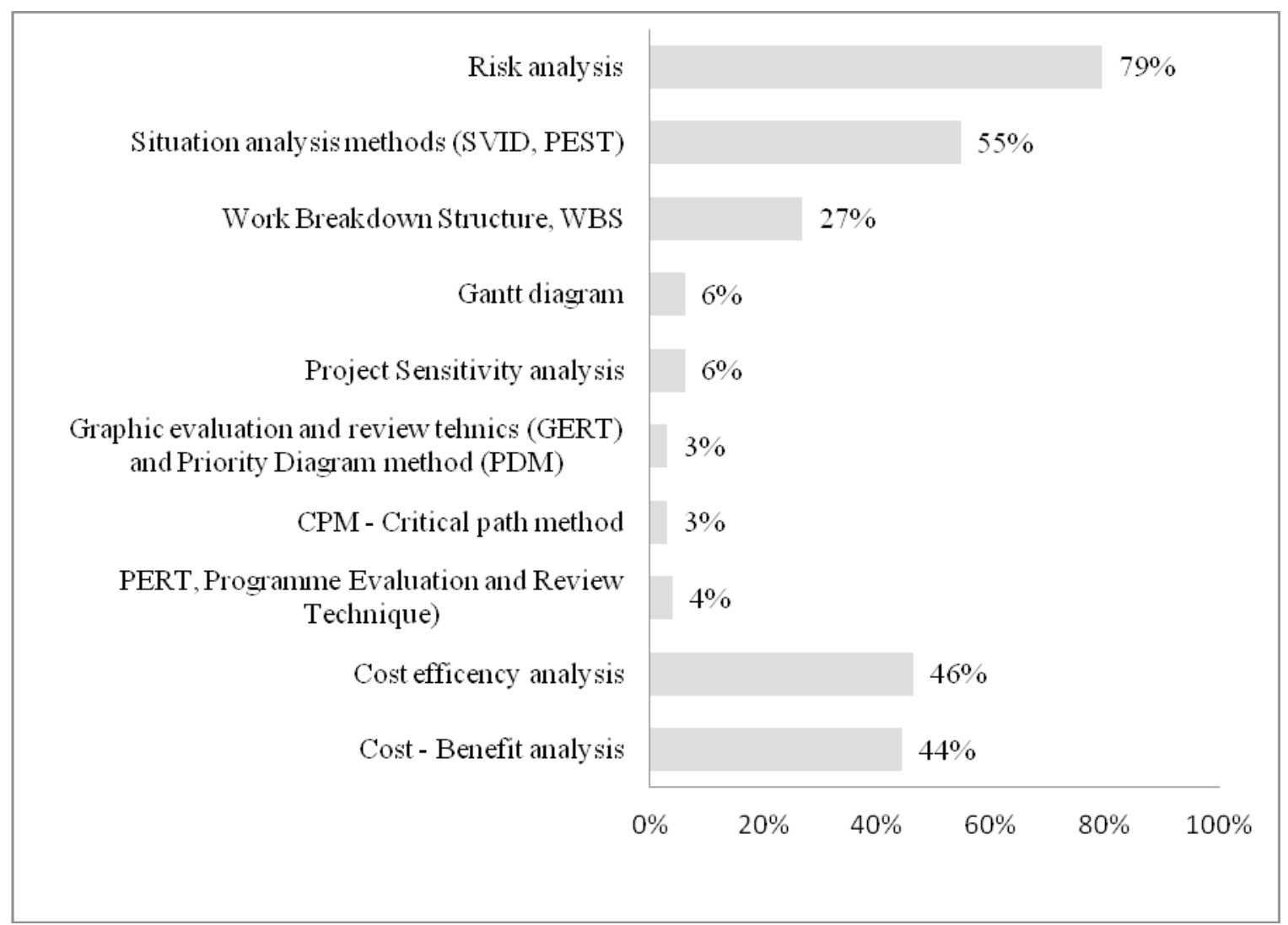

Figure 4. Project management methods applied in public sector project planning $(n=97)$

Source: author's empirical research

Figure 4 shows application of project management tools and technique in public sector project initialization, planning and implementation phases. Normally the project managers' criterion for choosing a methodology for any project is mainly based on an expert's opinion, past working experience, government rules and regulations, organization, senior management, stakeholder's preferences and client location. All of these can have positive or negative impact on the underdevelopment projects. However, all of the above mentioned criterion have inbuilt quality of rigidness. None of these provide any opportunity to analyses the nature of project and then decide the future course of action related to the selection of project management methodology. Decisions in which a methodology is chosen or used based on a single criteria can have serious negative impacts on the project especially if the project manager, development teams do not have the knowledge or the pros and cons of the selected methodology. No project management methodology is meant to be taken verbatim. It must be customized in the context in which it is being applied in order to increase the rate of adoption and the opportunity for success.

\section{Conclusions}

Public sector project realization planning represents a project management phase that encompasses goal definition and the determination of ways and measures for achieving the set goals, i.e., that the project is realized in the planned time, at the planned cost.

Study shows that self-assessment of public sector organizations in Latvia is quite high. Project management specialists define them self as very experienced in Project management, but meanwhile the self-assessment of organization project maturity (efficiency) levels shows that organizations is only at the beginning 
of setting up the appropriate Project management system. The public sectors project management usually is described as different kind of foreign financial instrument and program implementation.

To improve project management practice and efficiency in public sector in Latvia, author can recommend:

- To increase the capacity and professional skills level for local municipal project management staff (training programs, supervisions etc.).

- Define the appropriate organizational structure for project elaboration and implementation (matrix or pure project organization structures).

- Project management tools and techniques should be applied gradually (should be as an obligatory requirement in big scale public sector projects).

\section{References}

A Guide to the Project Management Body of Knowledge (PMBOK guide). (2013). 5th Edition. Project Management Institute.

Abbasi, Y. G., Al-Mharmah (2000). Project management practice by the public sector in a developing country. International Journal of Project Management, Vol. 18(3), p. 105-109.

Arnaboldi, M., Azzone, G., Avoldelli, A. (2004). Managing public sector project: the case of the Italian Treasury Ministry. International Journal of Project management, Vol. 22(3), p. 213-223.

Artto, K., Kujala, J., Dietrich, P., Martinsuo, M. (2008). What is project strategy? International Journal of Project Management, Vol. 26, p. 4-12.

Atkinson, R. (1999). Project management: cost, time and quality, two best guesses and a phenomenon, its time to accept other success criteria. International Journal of Project Management, Vol. 17, p. 337-342.

Boland, T., Fowler, A. (2000). A systems perspective of performance management in public sector organisations. The International Journal of Public Sector Management, Vol. 13, p. 417-446.

Bradley, J., Untiedt, G. (2008). EU cohesion policy and "conditional".

Brightman, H. (1978). Differences in Ill-Structured Problem Solving Along the Organizational Hierarchy. Decision Sciences, Vol. 9, Issue 1, p. 1-18.

Charvat, J. (2002). Project management nation. Jhon Willey \& Sons, inc.

Cleland, D. I. (1999). Project management: Strategic Design and Implementation. McGraw-Hill.

Cooke-Davies, T. J. (2001). Towards Improved Project Management Practice: Uncovering the evidence for effective practices through empirical research. $\mathrm{PhD}$ Thesis. Leeds Metropolitan University, Leeds.

Crawford, L., Pollack, J., England, D. (2006). Uncovering the trends in Project management: Journal emphases over the last 10 years. International Journal of Project Management, Vol. 24, p. 175-184.

Drucker, P. (2007). The effective executive. Elsevier.

Farrell, M. J. (1957). Decomposing Cost Efficiency.

Feasibility Study for asimplifying European Unionfund management system. (2009). Ltd.GFConsulting, 62 p.

Gower, D. G. (1992). Project management - an overview. Association of Project Managers. UK: UK Institution of Electrical Engineers professional brief.

Harpum, P. (2004). Project Control. In: Morris, P. W. G., Pinto, J. K. (eds.). The Wiley Guide to Managing the Projects. John Wiley and Sons, Inc.

Heerkens, R. (2007). Project management. New York: McGraw-Hill.

Kartam, N. A., Al-Daihani, T. G., Al-Bahar, J. F. (2000). Professional project management practices in Kuwait: issues, difficulties and recommendations. International Journal of Project Management, Vol. 18, p. 281-296.

Morgan, B. V. (1987). Benefits of project management at the front end. International Journal of Project Management, Vol. 5, p. 102-119.

Morris, P. W. G. (ed.) (1992). APM Body of Knowledge and Experience. Association of Project Managers. UK.

Ohara, S. (2005). Project and Program Management for Enterprise Innovation. PMAJ.

Patel, B. M. (2008). Project Management: Strategic financial planning, evaluation and control. New Delhi: Vikas Publishing House PVT Ltd.

Pinto, J. K. (2007). Project Management: Achieving Competitive Advantage. Upper Saddle River, NJ: Pearson Education

Pūlmanis, E. (2012). Evaluation of Regional Development financial instruments funded project management. First International Scientific Conference on Project Management in the Baltic Countries "Project Management Develop- 
ment - Practice and Perspectives". Riga, Latvia, February 8-9, 2012. Conference Proceedings. Riga: University of Latvia, $244 \mathrm{p}$.

Pūlmanis, E. (2013). Polycentric Development Projects Initialisation Process Problems in Latvia. Integrated and sustainable regional development: proceedings of the "International Scientific Conference Economic Science for Rural Development" (Economic science for rural development; No. 31). Jelgava: Latvia Agriculture University, p. 220-224.

Reiss, G. (1992). Project Management Demystified. E \& F Spon.

Rondinelli, D. A. (1976). Public planning and political strategy. Long Range Planning, Vol. 9, p. 75-82.

Rwelamila, P. M. D. (2007). Project management competence in public sector infrastructure organisations. Construction Management and Economics, Vol. 25, p. 55-66.

Soderlund, J. (2004a). Building theories of project management: past research, questions for the future. International Journal of Project Management, Vol. 22, p. 183-191.

Soderlund, J. (2004b). On the broadening scope of the research on projects: a review and a model for analysis. International Journal of Project Management, Vol. 22, p. 655-667.

Sprague, R. H., Carlson, E. D. (1982). Building Effective Decision Support Systems. Englewood Cliffs. New Jersey: Prentice-Hall.

Turner, J. R. (1996). International Project Management Association global qualification, certification and accreditation. International Journal of Project Management, Vol. 14, p. 1-6.

Van Gundy, A. B. Jr. (1988). Techniques of Structured Problem Solving. 2nd ed. New York: Van Nostrand.

\title{
VIEŠOJO SEKTORIAUS PROJEKTU VALDYMO EFEKTYVUMO PROBLEMOS, LATVIJOS ATVEJIS
}

\author{
EMīls PŪLMANIS \\ Valstybinè regioninės plètros agentūra (Latvija)
}

\section{Santrauka}

Projektų valdymo metodų taikymas besivystančių ekonomikų viešajame sektoriuje tampa vis svarbesnis, ypač tokiose valstybėse kaip Latvija, kur vykdoma daug įvairių projektų. Straipsnyje nagrinèjamos projektų valdymo praktikos Latvijos viešajame sektoriuje. Viešojo sektoriaus projektų valdymas pastaruoju metu Latvijoje tapo ypač populiarus, nes prieinami įvairūs viešo finansavimo šaltiniai. Straipsnyje aptariama Latvijos viešojo sektoriaus projektų valdymo praktika. Tyrimas parodè, kad viešojo sektoriaus projektų lygis yra žemas, ji būtina kelti. Tyrimas atliktas 2013 metais sausio - vasario mėnesiais.

PAGRINDINIAI ŽODŽIAI: projektu valdymas, projektu planavimas ir inicijavimas, efektyvumas.

JEL KLASIFIKACIJA: O220, H430, H540 